\title{
NILAI-NILAI PENDIDIKAN KARAKTER DALAM KUMPULAN CERITA RAKYAT DAERAH JAMBI KARYA H. ZUKRI NAWAS
}

\author{
Erlina Zahar', Nurani Lumban Tobing ${ }^{2}$ \\ Program Studi Pendidikan Bahasa dan Sastra Indonesia \\ Fakultas Keguruan dan Ilmu Pendidikan Universitas Batanghari \\ Jambi \\ erlina_zahar@yahoo.co.id \\ nuranilumbantobing@gmail.com
}

\begin{abstract}
This research aims to describe the educational character values in the collection of Cerita Rakyat Daerah Jambi by H. Zukri Nawas. There 9 aspects of educational character values; namely honesty, bravery, trustworthy, fair, thoughtful, responsible, confident, hardwork, and tolerance aspects. This study included a qualitative type of descriptive. Based on the results of data analysis, it is known that there are 50 quotations which are divided into 9 aspects of educational character as follows: 1) There are 5 quotations of honesty (always talking honestly, working honestly, and admitting any mistakes honestly); 2) there are 11 quotations of bravery aspect (having courage when starting something new and facing evil); 3) there are 5 quotations of trustworthy aspect (have an attitude of trust when carrying out their duties and obligations by exemplify good works; 4) there are 3 quotations of fairness aspect (fair in earning rights under its obligations); 5) there are 4 quotations of thoughtful aspect (have an attitude and right in the act accompanied by a mature thought; 6) there are 7 quotations of being responsible aspect (have a responsibility attitude when doing a job well done); 7) there is 1 quotation of confident aspect (having a high confidence when someone else is undoing it but he still remains at his own); 8) there are 8 quotations of hardworking aspect (have a hard work attitude that always try to get something he wants), and 9) there are 6 quotations of tolerance aspect (have a mutual respect). It can be concluded that there are some educational values found in the collection of Cerita Rakyat Daerah Jambi by H. Zukri Nawas. The aspects are honesty, bravery, trustworthy, fair, thoughtful, responsible, confident, hardwork, and tolerance.
\end{abstract}

Keywords: Educational Character Values, Jambi folklore

\footnotetext{
${ }^{1}$ Dosen Program Studi Pendidikan Bahasa dan Sastra Indonesia, Fakultas Keguruan dan Ilmu Pendidikan, Universitas Batanghari, Jambi

${ }^{2}$ Mahasiswa Program Studi Pendidikan Bahasa dan Sastra Indonesia, Fakultas Keguruan dan Ilmu Pendidikan, Universitas Batanghari, Jambi
}

Nilai-nilai Pendidikan Karakter dalam Kumpulan Cerita Rakyat Daerah Jambi Karya H. Zukri Nawas 


\section{PENDAHULUAN}

Karya sastra merupakan karya kreasi manusia, fenomena-fenoma kehidupan manusia dikreasikan oleh sastrawan ke dalam karya sastra. "Karya sastra merupakan suatu bentuk dan hasil pekerjaan seni kreatif yang objeknya adalah manusia dan kehidupannya menggunakan bahasa sebagai mediumnya" (Semi, 1988:8). Karya sastra merupakan gambaran dari kehidupan manusia pada umumnya dalam kehidupan nyata. Karya sastra juga tercipta dengan menggunakan bahasa yang indah, dengan begitu karya sastra akan selalu melekat dihati para pembacanya.

Karya sastra merupakan cabang seni, yaitu cipta ekspresi manusia yang indah. "Karya sastra adalah segala sesuatu yang tertulis atau tercetak yang dianggap menonjol. Bentuk dan ekspresi sastranya dan dipandang sebagai karya imajinatif yang memiliki kaitan dengan tulisan yang indah dan sopan" (Wiyatmi, 2009:14). Karya sastra merupakan karya yang dituangkan ke dalam tulisan yang mengandung kata-kata yang indah dan sopan. Karya sastra juga dapat dilihat sebagai karya sastra tulisan dan karya sastra lisan. Karya sastra lisan disebut dengan foklor, salah satu wujud dari foklor adalah cerita rakyat.

Salah satu bentuk naskah cerita rakyat yang ada di daerah Jambi yaitu kumpulan Cerita Rakyat Daerah Jambi karya H. Zukri Nawas. Cerita rakyat sebagai kebudayaan daerah yang menjadi ciri khas pada setiap bangsa yang mempunyai kultur budaya yang beraneka ragam. Cerita rakyat juga merupakan cerita yang berasal dari masyarakat dan berkembang dalam masyarakat pada masa lampau. Cerita rakyat mencakup kekayaan budaya dan sejarah yang dimiliki masing-masing daerah. "Cerita rakyat merupakan bentuk karya sastra yang hidup di tengah-tengah masyarakat dan ceritanya diturunkan secara lisan dari generasi ke generasi yang lebih muda" (Danandjaja, 2002: 3). Cerita rakyat yang termasuk kelompok dongeng, bersifat imajinatif, namun banyak pelajaran yang dapat dipetik. Cerita rakyat ini merupakan sastra lisan yang telah dituliskan. Cerita rakyat ini menjadi bacaan yang dapat dibaca oleh semua penikmat sastra, bahkan cerita rakyat ini sudah terdapat di media online. Cerita rakyat ini tidak kalah penting dengan jenis-jenis karya sastra yang lain. Cerita rakyat juga memilki kandungan makna atau isi pesan yang disampaikan. Cerita rakyat ini menampilkan karakter yang menjadi bacaan oleh penikmat sastra. Sehingga bermanfaat bagi masyarakat. Selain untuk menghibur, cerita ini dapat dijadikan sebagai acuan tuntutan pendidikan, khususnya pendidikan karakter bagi masyarakat.

Pendidikan karakter merupakan sebuah sistem keyakinan dan kebiasaan yang mengarahkan tindakan seorang individu. Pengetahuan mengenai pendidikan karakter dapat diketahui bagaimana individu tersebut bersikap untuk kondisi-kondisi tertentu. Pendidikan karakter itu akan membentuk motivasi. Pendidikan karakter memiliki arti sifat-sifat kejiwaan, akhlak atau budi pekerti yang membedakan seseorang dari yang lain. "Karakter merupakan cara berpikir dan berperilaku yang menjadi ciri khas tiap individu untuk hidup dan bekerja sama, baik dalam lingkungan keluarga, masyarakat, bangsa dan bernegara" Suyanto (dalam Azzet (2011:16)). Individu yang berkarakter baik bisa mempertanggungjawabkan setiap akibat dari keputusan yang dibuat. Dari 
pernyataan di atas, pendidikan karakter perlu diaplikasikan dalam kehidupan sehari-hari, terutama dalam kehidupan bermasyarakat.

Cerita rakyat Jambi merupakan bagian dari kebudayaan kearifan lokal. Kedudukan cerita rakyat dalam beberapa tahun terakhir semakin tergeser akibat kemajuan zaman dan teknologi. Beragam bentuk tradisi kebudayaan lama seperti cerita rakyat, akan terabaikan sehingga dikhawatirkan cerita rakyat di dalamnya terkandung nilainilai, norma-norma, dan adat istiadat, lama kelamaan akan hilang dari tengahtengah masyarakat (Djunaidi T. Noor dalam koran Jambi Independent dialog budaya 2017). Dalam cerita rakyat, banyak mengandung nilai-nilai pendidikan karakter yang harus dilestarikan oleh segenap warga negara Indonesia. Berdasarkan UU RI No.17 Tahun 2007 tentang RPJPN 2005-2025, bahwa saat ini program pembangunan jangka panjang pemerintah menekankan pada pendidikan karakter yang mencakup penguatan pendidikan karakter.

Fenomena sosial terakhir menunjukkan kepada kita bahwa nilai pendidikan karakter manusia telah bergeser oleh dampak globalisasi. Adanya globalisasi menimbulkan berbagai masalah terhadap kebudayaan daerah, diantaranya penurunan rasa cinta terhadap kebudayaan, gaya kebaratbaratan dan hilangnya sifat kekeluargaan. Salah satu contohnya yaitu nilai-nilai kejujuran sudah mulai berkurang dari budaya masyarakat akademik, karena pengaruh dari lingkungan. Padahal, nilai pendidikan karakter merupakan suatu pondasi yang sangat penting dan perlu ditanamkan sejak dini. Hal ini terlihat dari keseriusan pemerintah untuk membudayakan pendidikan karakter bagi anak bangsa ke dalam UU Nomor 87 tahun 2017.

Di dalam kumpulan Cerita Rakyat Daerah Jambi karya H. Zukri Nawas, ini mengandung nilai-nilai pendidikan karakter yang dapat menjadi pedoman bagi manusia. Oleh karena hal tersebut penelitian mengenai nilai-nilai pendidikan karakter dalam kumpulan cerita rakyat daerah Jambi karya $\mathrm{H}$. Zukri Nawas, penting untuk dilakukan.

\section{METODE PENELITIAN}

Dalam penelitian sastra terdapat beberapa sudut pandang atau pendekatan dalam menganalisisnya. Menurut Rahima (2016:1) perbedaan sudut pandang akan menimbulkan adanya berbagai jenis penelitian sastra, tergantung dari mana sudut pandang yang dipakai seorang peneliti, seperti penelitian deskriptif kualitataif.

Penelitian deskriptif kualitatif merupakan penelitian deskriptif yang menggunakan pendekatan kualitatif. "Penelitian kualitatif adalah penelitian yang digunakan untuk meneliti pada kondisi objek yang alamiah, dimana penulis adalah sebagai instrumen kunci, teknik pengumpulan data dilakukan, penelitiam kualitatif lebih menekankan makna dari pada generalisasi" (Sugiyono, 2016:1).

Penelitian kualitatif adalah jenis penelitian yang dilakukan untuk mendapatkan data. "Penelitian kualitatif dilakukan dengan tidak mengutamakan angka-angka, tetapi mengutamakan kedalaman penghayatan terhadap interaksi antar konsep yang sedang dikaji secara empiris" (Semi,2012:28). Penelitian kualitatif merupakan metode yang mampu menggunakan kata-kata baik tertulis maupun lisan berdasarkan fakta dan fenomena yang hidup dan akan berkembang. Jenis penelitian dilakukan 
untuk memperoleh dan mengumpulkan data. "Penelitian kualitatif dilaksanakan untuk membangun pengetahuan melalui pemahaman dan penemuan" (Danim, 2002:36). Jenis peneltian kualitatif dilakukan dalam upaya untuk memeperoleh data, lalu memahami data yang telah ditemukan.

"Deskriptif dapat diartikan sebagai prosedur pemecahan masalah yang diselidiki dengan mendeskripsikan atau melukiskan keadaan subjek atau objek penelitian pada saat sekarang berdasarkan fakta-fakta yang tampak atau sebagaimana adanya" (Siswantoro, 2010:56). Jenis penelitian deskriptif yaitu menggambarkan situasi. "Penelitian deskriptif merupakan suatu bentuk penelitian yang ditujukan untuk mendeskripsikan fenomena-fenomena yang ada, baik fenomena alamiah maupun fenomena buatan manusia" (Sukmadinata, 2006:72). Penelitian deskriptif digunakan untuk memecahkan masalah yang akan dianalisis guna mendapatkan hasil yang baik.

"Data adalah sumber informasi yang akan diseleksi sebagai bahan analisis." (Siswantoro, 2010:70). Data penelitian ini adalah kutipan-kutipan tentang nilai-nilai pendidikan karakter berupa kata-kata, kalimat, yang terdapat dalam kumpulan cerita rakyat daerah Jambi karya H. Zukri Nawas.

"Sumber data terkait dengan subjek penelitian dari mana data diperoleh" (Siswantoro, 2010:72). Sumber data penelitian ini bersumber dari buku cerita rakyat Jambi karangan H. Zukri Nawas.

Teknik pengumpulan data merupakan cara penulis untuk mengumpulkan data dalam penelitian. "Analisis konten adalah strategi untuk menangkap pesan dalam karya sastra" (Endraswara, 2013: 162). Pegumpulan data banyak menggunakan beberapa teknik. Pengumpulan data dalam penelitian ini menggunakan dokumentasi yang dilakukan untuk menganalisis isi dari cerita rakyat terutama Nilai-Nilai Pendididkan Karakter dalam kumpulan Cerita Rakyat daerah Jambi karya H. Zukri Nawas.

Teknik analisis data merupakan cara penulis untuk mengumpulkan data dalam penelitian. "Analisis data dilakukan dengan menjelaskan dalam bentuk deskriptif terhadap masingmasing data secara fungsional dan rasional" (Siswantoro, 2010:81). Data yang telah diperoleh dijelaskan dalam bentuk deskriptif. Adapun langkahlangkah analisis data sebagai berikut.

1. Data yang sudah dikelompokkan kemudian dimasukkan ke dalam tabel tabulasi data.

2. Menganalisis data sesuai dengan aspek nilai karakter tokoh dalam kumpulan Cerita Rakyat Daerah Jambi yang terdapat pada bagianbagian kutipan yang terkandung di dalam cerita rakyat.

\section{HASIL DAN PEMBAHASAN Hasil Penelitian}

Kumpulan Cerita Rakyat Daerah Jambi Karya H. Zukri Nawas ini memuat nilai-nilai ekstrinsik yakni nilai pendidikan karakter yang meliputi jujur, berani, amanah, adil, bijaksana, tanggung jawab, percaya diri, kerja keras, dan toleran. Dari 11 judul pada Kumpulan Cerita Rakyat Daerah Jambi Karya H. Zukri Nawas, ditemukan 50 kutipan yang menggambarkan 9 aspek nilai-nilai pendidikan karakter.

1. Aspek jujur dalam Kumpulan Cerita Rakyat Daerah Jambi Karya H. Zukri Nawas terdapat 5 kutipan. 
2. Aspek berani dalam Kumpulan Cerita Rakyat Daerah Jambi Karya H. Zukri Nawas terdapat 11 kutipan.

3. Aspek amanah dalam Kumpulan Cerita Rakyat Daerah Jambi Karya H. Zukri Nawas terdapat 5 kutipan.

4. Aspek adil dalam Kumpulan Cerita Rakyat Daerah Jambi Karya H. Zukri Nawas terdapat 3 kutipan.

5. Aspek bijaksana dalam Kumpulan Cerita Rakyat Daerah Jambi Karya H. Zukri Nawas terdapat 4 kutipan.

6. Aspek tanggung jawab dalam Kumpulan Cerita Rakyat Daerah Jambi Karya H. Zukri Nawas terdapat 7 kutipan.

7. Aspek percaya diri dalam Kumpulan Cerita Rakyat Daerah Jambi Karya H. Zukri Nawas terdapat 1 kutipan.

8. Aspek kerja keras dalam Kumpulan Cerita Rakyat Daerah Jambi Karya H. Zukri Nawas terdapat 8 kutipan.

9. Aspek toleran dalam Kumpulan Cerita Rakyat Daerah Jambi Karya H. Zukri Nawas terdapat 6 kutipan.

\section{Pembahasan}

Sembilan aspek yang menggambarkan nilai-nilai pendidikan karakter, tersebut dijelaskan sebagai berikut.

\section{Aspek Jujur}

"Jujur yakni sikap perilaku yang mencerminkan kesatuan antara pengetahuan, perkataan, dan perbuatan (mengetahui apa yang benar, mengatakan yang benar, dan melakukan yang benar) sehingga menjadikan orang yang bersangkutan sebagai pribadi yang dapat dipercaya" (Kemendiknas dalam suryai, 2013:1). Sikap jujur adalah suatu perilaku yang mencerminkan adanya kesesuaian hati perkataan dan perbuatan. Berikut contoh kutipan dari aspek jujur.

Kutipan 1
Sesampainya di ladang diberinya-lah bapaknya makan. Setelah bapaknya makan, beliau berkata "pergilah kau pulang, di rumah saja kau makan”. Ia pun pulang. Sesampai di rumah dia pun ditanya oleh ibunya, "sudahkah kau antar nasi bapakmu?" sudah (KCRJ PS: 10)

Pada kutipan 1 terdapat nilai pendidikan karakter aspek jujur tokoh anak. Kutipan tersebut dapat dianalisis dari dialog para tokoh. Dalam cerita tersebut terdapat nilai pendidikan karakter pada kutipan "sudahkah kau antar nasi bapakmu?" sudah kutipan tersebut termasuk salah satu aspek jujur, karena pada kalimat tersebut menjelaskan bahwa si anak sudah mengantar makanan bapaknya ke ladang dan ketika ibunya bertanya si anak menjawab dengan jujur. Perilaku tokoh anak terdapat di dalam kehidupan nyata, dan dapat dijadikan contoh dalam hidup bermasyarakat.

\section{Aspek Berani}

Berani merupakan sifat orang yang mau menghadapi rasa takut. Sikap berani mempunyai hati yang mantap dan rasa percaya diri yang besar untuk menghadapi kesulitan dan sebagainya. "Berani yaitu mempunyai hati mantap dan rasa percaya diri yang besar dalam menghapi bahaya, kesulitan, dan sebagainya, dan tidak takut" (Depdiknas, 1997:121). Berani dilandasi segala pertimbangan yang matang dan kekuatan hati yang kokoh. Berikut contoh kutipan dari aspek berani.

\section{Kutipan 2}

Sepeninggalan mereka itu tadi, bapaknya ini tidak menentu perasaannya lagi; ah melihat anak bagaimana perasaan kita seperti anda 
sendiri melihat putera atau puteri anda itu. Bagaimanakah caranya hidupku ini, kalau kawin dia di atas sungguh tidak aku berjumpa lagi dengan dia, tidaklah dia akan turun ke bawah alam dunia ini. "sekarang ayoklah kita, kalau berperang, berperanglah kita, itu kata ayahnya tadi kepada kemenakannya. (KCRJ PS: 16)

Pada kutipan 2 terdapat nilai pendidikan karakter aspek berani seorang ayah. Kutipan di atas dapat dianalis dari dialog parah tokoh. Dalam cerita tersebut terdapat nilai pendidikan karakter pada kutipan sekarang ayoklah kita, kalau berperang, berperanglah kita, itu kata ayahnya tadi kepada kemenakannya. Kutipan tersebut termasuk dalam salah satu nilai pendidikan karakter aspek berani karena kutipan tersebut menjelaskan perasaan seorang ayah yang tidak menentu, terpikir bagaimana kalo puterinya menikah dengan orang di atas langit, dia tidak terima. Jadi ayah tersebut memutuskan untuk berperang. Perilaku tokoh ayah tersebut mencerminkan karakter berani yang dilandaskan dengan segala pertimbangan yang matang dan kekuatan hati tokoh. Sikap tokoh ayah tersebut dalam kehidupan nyata, dapat dijadikan contoh dalam hidup bermasyarakat.

\section{Aspek Amanah}

Amanah merupakan sesuatu yang dipercayakan kepada orang lain. "Orang yang amanah lisan dan tidakannya sejalan, jika berjanji di tepati, dan apabila diberi kepercayaan dijaga dan ditunaikan dengan sebaik-baiknya" (Nashir, 2013:76). Berikut contoh kutipan dari aspek amanah.

Kutipan 3
Lama kelamaan sampailah hamil isteri itu tiga bulan, bernazarlah isterinya. Nazar isterinya itu, kalau sampai aku melahirkan anak perempuan aku membunuh kambing di dasar tangga rumah. Lama kelamaan sampailah hamil sembilan bulan, sampai harinya, melahirkanlah dia, perempuan anaknya. Rebahlah kabing di dasar tangga tadi dipotong lalu kendurilah mereka. (KCRJ PS: 9)

Pada kutipan 3 terdapat nilai Pendidikan karakter amanah tokoh isteri. Kutipan tersebut dapat dianalis dari dialog parah tokoh. Dalam cerita tersebut, terdapat nilai pendidikan karakter pada kutipan Rebahlah kabing di dasar tangga tadi dipotong lalu kendurilah mereka. Kutipan tersebut termasuk salah satu nilai-nilai pendidikan karakter aspek amanah karena pada kutipan tersebut menjelaskan tokoh isteri yang bernazar kalau sampai melahirlan anak perempuan maka akan dipotongnya kambing di dasar tangga rumah. Dan tidak lama kemudian diapun melahirkan seorang anak perempuan. Dipotonglah sapi dan mereka makan bersama untuk memperingati hari istimewa tersebut. Perilaku tokoh isteri mencerminkan sikap yang mampu untuk menepati amanah tersebut. Sikap tokoh isteri tersebut dapat dijadikan contoh dalam hidup bermasyarakat.

\section{Aspek Adil}

Adil adalah salah satu sikap yang tidak memihak. Tidak ada lebih dan tidak ada kurang. "Adil adalah istilah yang digunakan untuk menunjukkan pada persamaan atau bersikap tengahtengah atas dua perkara" (Fakhrudin (dalam Abuddinanta, 203:144)). Adil adalah menempatkan sesuatu pada posisinya secara tepat dan benar. Setiap 
manusia ingin mendapatkan keadilan. Berikut contoh kutipan dari aspek adil.

Kutipan 3

Begini anak muda. Kita saling bertaruh dan berhadiah. Ah, bagaimana saling berhadiah itu; aku tidak tahu tentang itu, kakek. Terserahlah kepada kakek bagaimana baiknya; akau tidak tahu. Begini, kalau ayammu kalah, kamu tinggal bersamaku di sini. Baiklah kalau begitu; kalau ayam kakek kalah bagaimana? Apa keiginanmu? Keinginanku saat ini ialah alat lat besi. (KCRJ APBN: 41)

Pada kutipan 3 terdapat nilai Pendidikan karakter tokoh adil. Kutipan tersebut dapat dianalis dari dialog parah tokoh. Dalam cerita tersebut terdapat nilai pendidikan karakter pada kutipan Begini, kalau ayammu kalah, kamu tinggal bersamaku di sini. Baiklah kalau begitu; kalau ayam kakek kalah bagaimana? Apa keiginanmu? Keinginanku saat ini ialah alat lat besi. Kutipan tersebut termasuk salah satu nilai pendidikan karakter aspek berani, karena kutipan tersebut menjelaskan saat mereka bertarung lagi, kakek mengatakan kalau ayammu kalah, kamu tinggal bersamaku dan kalo ayam kakek yang menang katakanlah keinginanmu. Perilaku kakek tersebut mencerminkan karakter adil, keduanya mendapatkan hak yang sama. Sikap tokoh kakek tersebut, dapat dijadikan contoh dalam hidup bermasyarakat.

\section{Aspek Bijaksana}

Bijaksana sama halnya dengan arif. Orang bijak atau bijaksana dikesankan sebagai manusia yang pandai mengambil sikap, keputusan, dan tindakan yang tengahan atau moderat dari berbagai hal yang ekstrime" (Nashir, 2013:80). Sikap bijaksana merupakan sikap tepat dalam menyikapi setiap keadaan yang ada, sehingga memancarlah keadilan. Orang yang bijaksana tentu pandai mengambil keputusan dan tindakan. Berikut contoh kutipan dari aspek bijaksana.

Kutipan 4

Hai musang, pergilah kaulihat siapakah yang menggangu aku di rumah barusan ini, tidaklah dimakannya bubur kami pergi kau lihat, lihatlah kami ini sudah kena begini. Kalau tentu siapa orangnya, kalau itu nantinya, kumakan manusia itu. Ambillah untukmu pepayaku yang ada di sekeliling ini semuanya. Baiklah kalau begitu kata musang. (KCRJ BB: 75)

Pada kutipan 4 terdapat nilai pendidikan karakter bijaksana tokoh aku. Kutipan di atas dapat dianalis dari dialog parah tokoh. Dalam cerita tersebut terdapat nilai pendidikan karakter pada kutipan pergilah kaulihat siapakah yang menggangu aku di rumah barusan ini, tidaklah dimakannya bubur kami pergi kau lihat, lihatlah kami ini sudah kena begini. Kalau tentu siapa orangnya, kalau itu nantinya, kumakan manusia itu. Ambillah untukmu pepayaku yang ada di sekeliling ini semuanya. Kutipan tersebut termasuk salah satu nilai pendidikan karakter aspek bijaksana karena pada kutipan tersebut menjelaskan tokoh aku menggambil tindakan, dan memerintah musang untuk mencari tau siapa yang mengganggu di rumahnya. Kemudian musang akan mendapatkan upahnya yaitu pepaya milik tokoh aku. Perilaku tokoh aku mencerminkan karakter bijaksana dalam mengambil tindakan.

\section{Aspek Tanggung Jawab}


Sikap tanggung jawab perlu ditumbuhkan di kalangan masyarakat. "Tanggung jawab merupakan sikap dan perilaku seseorang dalam melaksanakan tugas dan kewajibannya, baik yang berkaitan dengan diri sendiri, sosial, masyarakat, bangsa, negara maupun agama" (Kemendikbud, 2010). Tanggung jawab juga dapat diartikan sebagai perwujudan kesadaran orang terhadap kewajibannya. Berikut contoh kutipan dari aspek tanggung jawab.

Kutipan 5

Bagaimana pula cara kita membuat perjanjian lagi? Sedangkan dulunya kamu telah menang. Sekarang pasti kau kalah. "kalau aku kalah, ya apa boleh buat; aku tinggal bersama kakek disini. Perjanjian itu sama dengan cara yang dulu. (KCRJ ANBTBB: 44)

Pada kutipan 5 terdapat nilai pendidikan karakter tanggung jawab tokoh aku. Kutipan tersebut dapat dianalis dari dialog parah tokoh. Dalam cerita tersebut terdapat nilai-nilai pendidikan karakter pada kutipan Kalau aku kalah, ya apa boleh buat; aku tinggal bersama kakek disini. Perjanjian itu sama dengan cara yang dulu. Kutipan tersebut termasuk salah satu nilai pendidikan karakter aspek tanggung jawab karena pada kutipan tersebut menjelaskan tokoh aku yang akan menepati, melaksanakan janji yang telah diucapkan, jika tokoh aku kalah dia akan tinggal bersama kakek. Perilaku tokoh aku mencerminkan karakter tanggung jawab. Sikap tokoh aku tersebut dapat dijadikan contoh dalam hidup bermasyatakat.

\section{Aspek Percaya Diri}

Percaya diri merupakan sikap yakin pada kemampuan diri sendiri dalam melakukan tugas. "Percaya diri merupakan suatu sikap atau keyakinan atas kemampuan diri sendiri sehingga dalam tindakan-tindakannya tidak terlalu cemas, merasa bebas untuk melakukan hal yang sesuai dengan keinginan. Mengenal kelebihan dan kekuranga diri sendiri" (Lauster, 2002:4). Jadi percaya diri adalah suatu keyakinan seseorang terhadap kemampuan diri sendiri. Berikut contoh kutipan dari aspek percaya diri.

Kutipan 6

Ah, kita cobalah dulu. Aku tak dapat berbicara takabur, karena marah Tuhan kepada kita, kata anak piatu itu. Tadi kakek telah memastikan ayamku itu pastilah kalah (KCRJ APBN: 47)

Pada kutipan 6 terdapat nilai Pendidikan karakter percaya diri tokoh aku. Kutipan tersebut dapat dianalis dari dialog parah tokoh. Dalam cerita tersebut, terdapat nilai pendidikan karakter pada kutipan $\boldsymbol{A h}$, kita cobalah dulu. Aku tak dapat berbicara takabur, karena marah Tuhan kepada kita. Kutipan tersebut termasuk salah satu nilai pendidikan karakter aspek percaya diri karena kutipan tersebut menjelaskan sikap anak piatu yang tetap ingin mencoba lagi dan mempunyai rasa percaya diri. Anak piatu yakin pada diri sendiri, dia tidak mau mendengar perkataan orang yang meremehkan dirinya. Perilaku tokoh anak piatu mencerminkan karakter percaya diri, jelas tergambar bahwa karakter sikap percaya diri tokoh anak piatu yang memiliki keyakinan atas kemampuan diri sendiri sehingga tidak cemas.

\section{Aspek Kerja Keras}

"Kerja keras adalah perilaku yang menunjukkan upaya sungguhsungguh dalam mengatasi berbagai 
hambatan guna menyelesaikan tugas, pekerjaan dengan sebaik baiknya" (Mustari, 2011: 51-52). Kerja keras merupakan usaha yang dilakukan seseorang dengan sungguh-sungguh untuk mencapai tujuan dan tidak mudah putus asa. Berikut contoh kutipan dari aspek kerja keras.

\section{Kutipan 7}

"Dimanakah ada air? saya haus sekali. "Cobalah berjalan ke padang kunyit oranng mudik itu. Biasanya ada orang membawa saya tempat daun kunyit mungkin ada air tenggelam di dalamnya." Pergilah puti sri bulan ke padang kunyit itu. Tuhan mentakdirkan bertemulah dengan ia air tergenang dalam sayak jernih nian air itu. Lalu diminumlah oleh putri. (KCRJ: 146)

Pada kutipan 7 terdapat nilai Pendidikan karakter kerja keras tokoh Puti Sri Bulan. Kutipan di atas dapat dianalis dari dialog parah tokoh. Dalam cerita tersebut terdapat nilai pendidikan karakter pada kutipan Tuhan mentakdirkan bertemulah dengan ia air tergenang dalam sayak jernih nian air itu. Lalu diminumlah oleh putri. Kutipan tersebut termasuk salah satu nilai nilai pendidikan karakter aspek kerja keras karena pada kutipan tersebut menjelaskan Puti Sri Bulan yang berusaha mencari air karena kehausan, lalu pergilah Puti Sri Bulan ke padang kunyit baru bertemu dengan air yang jernih. Perilaku tokoh Putri Sri Bulan mencerminkan karakter kerja keras tokoh Puti Sri Bulan berusaha dengan sugguh-sungguh.

\section{Aspek Toleran}

Toleran yaitu sikap menghargai atau menghormati setiap tindakan yang dilakukan orang lain. "Toleran yakni sikap dan perilkau yang mencerminkan penghargaan terhadap perbedaan agama aliran kepercayaan, suku, adat, bahasa, ras, etnis, pendapat, dan hal-hal lain yang berbeda dengan dirinya secara sadar dan terbuka, serta dapat hidup tenang di tengah perbedaan tersebut" (Kemendikbud, 2010). Toleran merupakan sikap yang menggambarkan penghargaan terhadap berbagai perbedaan. Berikut contoh kutipan dari aspek toleran.

Kutipan 8

Apa ada orang yang kemalingan, atau bagaimana apa ada orang berkelahi. Dijawab datuk badaro kayo semua itu tidak ada, hanya kami kehilangan anak namanya puteri embun gemilir. Menyahutlah anak cerdik pandai: "bagaimana akal kita mencari dan menemukannya? Baiklah kita panggil ahli nujum".(KCRJ: 121)

Pada kutipan 8 terdapat nilai Pendidikan karakter toleran tokoh anak cerdik. Kutipan tersebut dapat dianalis dari dialog parah tokoh dalam cerita tersebut terdapat nilai pendidikan karakter pada kutipan Menyahutlah anak cerdik pandai: "bagaimana akal kita mencari dan menemukannya? Baiklah kita panggil ahli nujum. Kutipan tersebut termasuk salah satu nilai pendidikan karakter aspek kerja keras karena pada kutipan tersebut menjelaskan sikap anak cerdik itu terhadap Datuk Badaro yang kehilangan putrinya, anak cerdik itu menyahut bagaimana akal kita mencari dan menemukannya. Perilaku tokoh anak cerdik yang memiliki sikap toleran terhadap Datuk Badaro.

\section{SIMPULAN}

Berdasarkan hasil analisis data, dapat disimpulkan bahwa terdapat sembilan aspek nilai-nilai pendidikan 
karakter di dalam Kumpulan Cerita Rakyat Daerah Jambi karya H. Zukri Nawas. Kesembilan aspek tersebut adalah sebagai berikut.

1. Aspek jujur dalam Kumpulan Cerita Rakyat Daerah Jambi Karya H. Zukri Nawas terlihat dari dialog para tokoh dalam cerita tersebut dengan selalu mengatakan yang benar, mengakui setiap kesalahan yang diperbuat, melakukan yang benar sesuai dengan kenyataan. Terdapat 5 kutipan terkait dengan aspek jujur dalam Kumpulan Cerita Rakyat Daerah Jambi Karya H. Zukri Nawas.

2. Aspek berani dalam Kumpulan Cerita Rakyat Daerah Jambi Karya H. Zukri Nawas terlihat dalam kegiatan yang dilakukan para tokoh. Tokoh cerita tersebut memiliki keberanian yang tinggi dalam menghadapi rasa takut, berani dalam setiap tindakannya dan mengambil keputusan dengan pertimbangan yang matang. Terdapat 11 kutipan terkait aspek berani dalam Kumpulan Cerita Rakyat Daerah Jambi Karya H. Zukri Nawas.

3. Aspek amanah dalam Kumpulan Cerita Rakyat Daerah Jambi Karya H. Zukri Nawas terlihat dari perilaku tokoh yang ketika berjanji ditepati, diberi kepercayaan dijaga sebaik-baiknya dan dilaksanakan. Terdapat 5 kutipan terkait aspek amanah dalam Kumpulan Cerita Rakyat Daerah Jambi Karya H. Zukri Nawas.

4. Aspek adil dalam Kumpulan Cerita Rakyat Daerah Jambi Karya H. Zukri Nawas terlihat dari dialog parah tokoh yang tidak memihak, dan tidak pilih kasih. Terdapat 3 kutipan terkait aspek adil dalam
Kumpulan Cerita Rakyat Daerah Jambi Karya H. Zukri Nawas.

5. Aspek bijaksana dalam Kumpulan Cerita Rakyat Daerah Jambi Karya H. Zukri Nawas tercermin dari dialog parah tokoh bijaksana dalam menyikap setiap keadaan, bijak dalam mengambil keputusan. Terdapat 4 kutipan terkait aspek bijaksana dalam Kumpulan Cerita Rakyat Daerah Jambi Karya $\mathrm{H}$. Zukri Nawas.

6. Aspek tanggung jawab dalam Kumpulan Cerita Rakyat Daerah Jambi Karya H. Zukri Nawas terlihat dari dialog parah tokoh yang bertanggung jawab melakasanakn tugas dan kewajibannya yang seharusnya dilakukan, terhadap diri sendiri, masyarakat, negara, serta terhadap Tuhan yang Maha Esa. Terdapat 7 kutipan terkain aspek tanggung jawab dalam Kumpulan Cerita Rakyat Daerah Jambi Karya H. Zukri Nawas.

7. Aspek percaya diri dalam Kumpulan Cerita Rakyat Daerah Jambi Karya H. Zukri Nawas tercermin dari dialog tokoh yakin pada kemapuan diri sendiri dalam melakukan setiap hal, percaya akan kemampuan, percaya akan kelebihan, dan percaya akan kekurangan. Terdapat 1 kutipan terkait aspek percaya diri dalam Kumpulan Cerita Rakyat Daerah Jambi Karya H. Zukri Nawas.

8. Aspek kerja keras dalam Kumpulan Cerita Rakyat Daerah Jambi Karya H. Zukri Nawas terlihat dari dialog para tokoh dalam cerita tersebut yang sungguh-sungguh tanpa mengenal lelah.Terdapat 8 kutipan terkait aspek kerja keras dalam Kumpulan Cerita Rakyat Daerah Jambi Karya H. Zukri Nawas. 
9. Aspek toleran dalam Kumpulan Cerita Rakyat Daerah Jambi Karya H. Zukri Nawas terlihat dari dialog tokoh yang saling menghormati dan menghargai antar individu. Terdapat 6 kutipan terkait aspek toleran dalam Kumpulan Cerita Rakyat Daerah Jambi Karya H. Zukri Nawas.

Berdasarkan analisis kutipankutipan Nilai pendidikan karakter dalam Kumpulan Cerita Rakyat Daerah Jambi Karya H. Zukri Nawas, aspek paling dominan adalah aspek berani dan aspek yang kurang dominan adalah aspek percaya diri.

\section{DAFTAR PUSTAKA}

Azzet, Akhmad Muhaimin. (2011). Urgensi Pendidikan Karakter di Indonesia. Jogjakarta: Ar Ruzz Media.

Danandjaja, James. (2002). Foklor Indonesia.

Jakarta: Pustaka Utama Grafiti.

Danim, Sudarwan. (2012). Menjadi Peneliti Kualitatif. Bandung: Pustaka Setia

Endaswara, Suwardi. (2013). Metodologi

Penelitian Sastra. Yogyakarta: PT Buku Seru.

Lauster, Peter. (2002). Tes Kepribadian (Ahli Bahasa: D.H Gulo). Edisi Bahasa Indonesai. Jakarta: Bumi Aksara.

Mustari, Mohamad. (2011). Nilai Karakter: Refleksi untuk Pendidikan Karakter. Yogyakarta: Laksbang Pressindo.

Nashir, Haedar. (2013). Pendidikan Karakter Berbasis Agama dan Budaya.
Nawas, H. Zukri. Kumpulan Cerita Rakyat Daerah Jambi. Yogyakarta: Multi Presindo.

Rahima, A. (2017). Literature Reception (a Conceptual Overview). Jurnal Ilmiah Dikdaya, 6(1), 1-16.

Semi, M. Atar. (2012). Metode Penelitian Sastra. Bandung: CV Angkasa.

Siswantoro. (2010). Metode Penelitian Sastra Analisis Struktur Puisi. Yogyakarta: Pustaka Pelajar.

Sukmadinata, (2006). Metode Penelitian Kualitatif. Bandung: Graha Aksara

Wiyatmi. (2009). Pengantar Kajian Sastra. Yogyakarta: Pustaka Book Publisher. 